\title{
ZUSGS
}

science for a changing world

\section{Processed Thematic Mapper Satellite Imagery for Selected Areas within the U.S.-Mexico Borderlands}

By John C. Dohrenwend1', Floyd Gray², and Robert J. Miller3

Open File Report 00-309

Version 1.0

2001

This report is preliminary and has not been reviewed for conformity with U.S. Geological Survey (USGS) editorial standard nor with the North American stratigraphic codes.

U.S. Department of the Interior

Gale A. Norton, Secretary

U.S. Geological Survey

Charles G. Groat, Director

1 PO Box 141, Teasdale, UT 84773

2 U.S. Geological Survey, Tucson, Ariz.

3 U.S. Geological Survey, Menlo Park, Calif. 


\section{INTRODUCTION}

Landsat Thematic Mapper (TM) satellite full-scene images have been selected and processed for a large portion of the United States-México transborder region (Figure 1 and Figure 2, see TM_index.jpg). The Landsat TM images included on these CD-ROMs are digital color composites of middle, near infrared and visible light derived from TM bands 7, 4 and 2. The characteristics of the images were selected to facilitate coregistration with standard UTM projected map data and facilitate usage in a broad range of GIS and other graphical platforms.

The passage of the North American Free Trade Agreement (NAFTA), establishment of the Border Environmental Cooperation Commission (BECC) as well as the EPA U.S./México Border XXI Program have focused attention on the environmental, social-cultural, and economic conditions in the United States-México frontier and to the enhanced necessity of a binational, transborder approach in addressing problems. Currently, the border region is the location of numerous data collection and research activities by state and national government entities, nongovernment organizations (NGOs), and universities. Much of the work being done recognizes that the region's physical setting, ecological zones, and human phenomena extend uninterrupted across the international boundary and cannot be understood if restricted to one side of the border. Researchers and land managers representing both countries need current, accurate, and binationally compatible geospatial information to deal with such issues as water availability and pollution, natural resource sustainability, and human health. Towards this end, this assembled U.S.-México borderlands Thematic Mapper imagery is designed to be utilized as a fundamental part of a basic geographic information system database for natural resource, environmental, and land-management studies.

\section{DISCLAIMERS}

This Compact Disc-Read-Only-Memory (CD-ROM) publication was prepared by an agency of the United States Government. Neither the United States Government nor any agency thereof, nor any of their employees, makes any warranty, expressed or implied, or assumes any legal liability or responsibility for the accuracy, completeness, or usefulness of any information, apparatus, product, or process disclosed in this report, or represents that its use would not infringe privately owned rights. Reference therein to any specific commercial product, process, or service by trade name, trademark, manufacturer, or otherwise does not necessarily constitute or imply its endorsement, recommendation, or favoring by the United States Government or any agency thereof.

Although all data and software published on this CD-ROM set have been used by the USGS, no warranty, expressed or implied, is made by the USGS as to the accuracy of the data and related materials and (or) the functioning of the software. The act of distribution shall not constitute any such warranty, and no responsibility is assumed by the USGS in the use of this data, software, or related materials.

Any use of trade, product, or firm names is for descriptive purposes only and does not imply endorsement by the U.S. Government. 


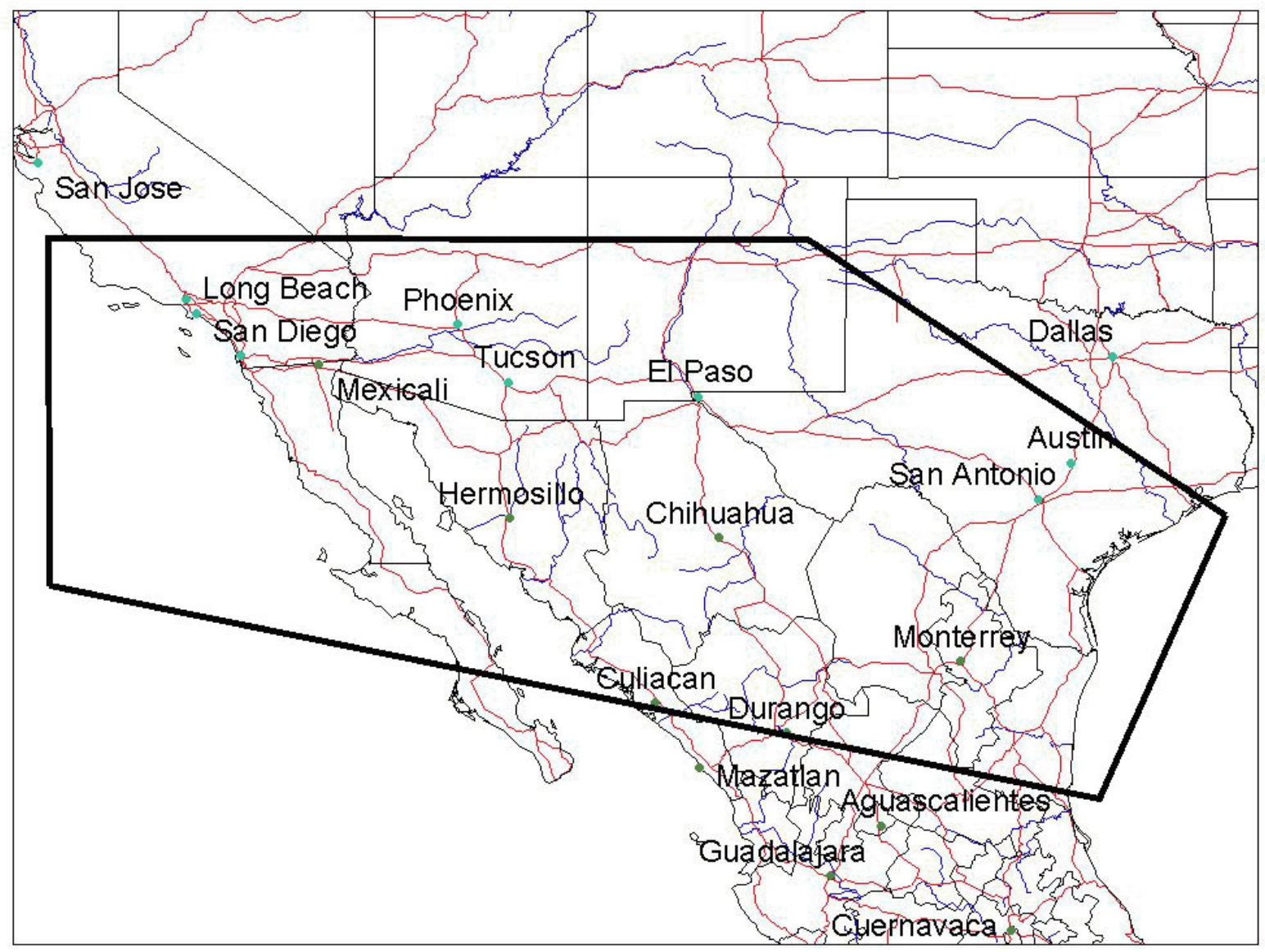

Figure 1. General location map of the United States-México transborder region (within heavy black line).

\section{SELECTED AREAS OF THEMATIC MAPPER COVERAGE}

The following geographical areas and their associated issues highlight regions of the U.S.-México borderlands that merit mention as regions where special international cooperation is warranted (see U.S./México Border XXI Program Framework Document for further details: U.S. EPA, 1996). The USGS Bureau Border Strategy Team* highlighted many of the areas as ideal sites for implementing an interdisciplinary research approach . These areas have been selected because of their relevance to border-wide information needs, their importance to management decisions by international, federal, state, local, and tribal agencies, and the critical nature of habitat, resource, or sustainable development issues. Within each area, broad objectives have been identified as guidelines for future studies. For each of these areas, a cross-border consistent database is a fundamental first step in addressing these complex issues.

\footnotetext{
* U.S. Geological Survey Border Strategy Team includes Denny Buckler, Ken Osborn, John Klein, Floyd Gray, Lloyd
} Woosley, Terry Rees, and Diana Papoulias 


\section{San Diego -Tijuana Urban Corridor (Image 40_37 provides coverage of this area)}

Issues and objectives: The rapidly growing San Diego-Tijuana urban corridor is located in one of the most seismically active areas of North America. Critical landscape and natural-resource issues include the disruptive effects of earthquakes, landslides, and floods on urban infrastructure, and the effects of urbanization on water resources. The principal water resource issues include balancing water demand and supply (imported), and polluted runoff from both countries. Urban flooding, sedimentation of coastal estuaries, and flood-plain management are additional issues affecting the area. A basic objective of a resource-based effort would be to characterize the linkages between natural hazards and urbanization and develop tools to effectively manage complex watersheds for the benefit of both humans and indigenous species.

\section{Salton Sea (Image 39_37 provides coverage of this area)}

Issues and objectives: The Salton Sea, a 35-mile long inland, hypersaline lake in southern California, is located in the lowest portion of a desert valley. Legally designated as a repository for irrigation drain water, the Sea has been the subject of considerable negative publicity for several years. Increasing salinity, rising and/or falling water-surface elevations, and wildlife mortalities all have contributed to the loss of value for the Sea and surrounding area. The most recent outbreak (1996) of avian botulism claimed approximately 20\% of the total Pacific Flyway population of endangered brown pelicans. This was followed in 1997 by an outbreak of Newcastle's disease. All of these issues have focused the problems of the Salton Sea for federal agencies, Congress, state and local agencies, and the public. The overall objective of assessing ecosystem health from a multidisciplinary scientific perspective is preeminent for this region of the border.

Colorado River Delta - Baja California (Images 37_38, 38_38, and 39_38 provide coverage of this area)

Issues and Objectives: The Colorado River Delta and the northern Baja California region include many protected areas that are rich in biodiversity and natural beauty, including: the Sierra de San Pedro Martin National Forest Reserve, the Alto Golfo de California - Delta del Rio Colorado Biosphere Reserve, the Cienega de Santa Clara, and the Pinacate - Gran Desierto de Altar Biosphere Reserve. The delta of the Colorado River in México is among the world's great desert estuaries and supports freshwater, brackish, and intertidal wetlands that represents important wintering habitat for migratory waterfowl. These wetlands contain the only populations of substantial size of a variety of endangered species, such as Desert Pupfish and Yuma Clapper Rail. The marine zone of the Alto Golfo de California - Delta Rio Colorado Biosphere Reserve contains rare and endangered marine species, some of which have been severely affected by overexploitation. Residual flows from the US. by way of the Colorado River into México along with irrigation return flows and brine waters have dramatically affected the ecology of the upper Gulf of California and the Cienega de Santa Clara. An informed binational water management plan for flood and irrigation -return fresh water inflow into the delta is required to adequately maintain the remaining vital wetlands. 
San Pedro-Santa Cruz Basins (Images 36_38, 35_39, and 35_38 provide coverage of this area)

Issues and objectives: The primary natural-resource issues associated with these basins are limited water quantity, impaired water quality and potential impacts of mining operations. Water in the San Pedro River is supplied by flows that originate in México and by discharge from the adjacent aquifers. Management challenges include maintenance of sufficient flows for the protection of riparian environments, resolution of conflicting water-use interests, legal determination of water rights, and identification of the effects of water-resources development in the upper reaches in México. Acidic water due to mineral deposits and tailings dam failures in México have had significant impacts on downstream habitats, and often sewage effluent makes up the majority of the flow in the Santa Cruz River. Ground water in the Nogales area is contaminated by infiltration of sewage and industrially derived water. Pressing watermanagement decisions are being made without an adequate understanding of the origin of surface flows, ground water-surface water interactions, subbasin subsurface configuration, and the importance of the riparian system. The main objectives of border studies in this region are to: 1) Characterize natural-resource conditions, in particular subbasin analysis on the Mexican side of the border. Investigations would include characterization of the geologic framework necessary for ground-water resource assessment, and identification of possible sources of acid drainage within the watersheds; and 2) Partner with México to provide binational aerial photography, fully integrated geospatial data, and watershed delineation at high resolution using a geographical information system (GIS).

\section{El Paso-Ciudad Juarez Metropolitan Area (Images 33_37 and 33_38 provide coverage of this area)}

Issues and objectives: The El Paso-Ciudad Juarez metropolitan area is another fast growing area of the border region. The critical natural-resource issue is the availability of water. While the conjunctive use of ground and surface water is satisfying immediate water needs, additional demands imposed by projected growth will exceed the capacity of the area's limited water resources. Ground-water withdrawals have resulted in land-surface subsidence. Other issues include untreated industrial and municipal wastewater and polluted runoff. The need to define and predict natural-resource limitations requires some basic objectives including: 1) Characterization of the effects of urbanization on the limited natural habitats; 2) Characterization of the mechanics of land-surface subsidence associated with ground-water withdrawals; 3 ) Development of binationally compatible digital geospatial information systems; and 4) Characterization of regional hydrology including pollutant reservoirs and transport modeling.

Big Bend National Park and Adjacent Protected Areas (Images 30_39, 30_40, 31_39, and 31_40 provide coverage of this area)

Issues and objectives: The United States and México have designated a significant portion of the Chihuahuan Desert landscape for protection of natural resources. These areas include Big Bend National Park, Rio Grande Wild and Scenic River, Big Bend Ranch State Natural Area, Black Gap Wildlife Management Area, and Santa Elena Cañon and Maderas del Carmen Protected 
Areas. Resource managers in the area are in need of additional scientific information and geospatial data to optimize their resource protection efforts. Limited water availability and impaired water and air quality are primary concerns. Additionally, information pertaining to the status of biological resources within this area is quite limited. The primary research objectives are to provide scientific information on regional resources for management of protected areas including conduct regional coal assessments and characterization and assessment of mineral resource potential.

Rio Grande River below Falcon International Dam (Images 26_41 and 26_42 provide coverage of this area)

Issues and objectives: The Rio Grande watershed below Falcon International Dam, including the Arroyo Colorado, is one of the fastest growing areas of the border region. The critical naturalresource issue in the area is the availability of water for satisfying human and agricultural needs while providing sufficient streamflows to maintain and enhance stream and associated riparian habitats. Available streamflows of the Rio Grande are fully allocated under international treaty. Minimum instream-flow volumes and peaks necessary to support indigenous species and riparian habitat have not been determined. Also of critical concern is the quality of water and the effects of contaminants on species, habitats, and use of the resource. Polluted urban runoff, undertreated industrial and municipal wastewater, agricultural practices, and coal mining are other issues. The main objective for this region is to characterize watershed conditions, define instream flow requirements, and develop tools to effectively manage complex watersheds for the benefit of both humans and indigenous species.

South Padre Island -Laguna Madre de Tamaulipas (Images 26_41 and 26_42 provide coverage of this area)

The Tamaulipan ecosystem extends throughout Texas and northeastern México and includes a host of protected areas such as the Lower Rio Grande, Laguna Atascosa and Santa Ana Natural Wildlife Refuges, Padre Island National Seashore, as well as state and privately- owned habitat management areas. The Rio Grande River system is the major watershed within this ecosystem and is essential to the survival of resident and migratory fauna and existing flora; in addition, the narrow riparian corridor of the Rio Grande provides habitat for endangered species and nesting for wintering birds, among them unique species of neotropical affinities. The vast Laguna Madre is one of only two large hypersaline lagoons in the world and therefore hosts a unique biodiversity within its productive estuaries that maintains a base for an important commercial and recreational fishing industry. Monitoring programs have recently been initiated in the Gulf of México that addresses coastal and shoreline erosion, freshwater inflow, habitat degradation, aquatic resources, nutrient enrichment, public health, marine debris, and toxic substances and pesticides. A constant awareness of the status of western Gulf of Mexico natural resources will require increased multidisciplinary information exchange.

\section{IMAGE CHARACTERISTICS}

These satellite images were produced from data acquired by the Thematic Mapper (TM) scanner 
of the Landsat 4 and Landsat 5 satellites (Table 1). These images have been projected to the Universal Transverse Mercator (UTM) grid so that they can be compared directly with U.S. Geological Survey 1:100,000-scale topographic maps and Instituto Nacional de Estadistica Geografia e Informatica 1:50,000-scale maps of the Borderlands region. Post spacing (the smallest area for which data are collected) is $30 \mathrm{~m}$ by $30 \mathrm{~m}$ ( $98 \mathrm{ft}$ by $98 \mathrm{ft}$ ). However, each data file has been digitally resampled to $28.5 \mathrm{~m}$ by $28.5 \mathrm{~m}$ pixels so that 5 pixels on the satellite image represents an area of one acre on the Earth's surface. The area represented by each image file is approximately $33,000 \mathrm{~km}^{2}\left(12,700 \mathrm{mi}^{2}\right)$.

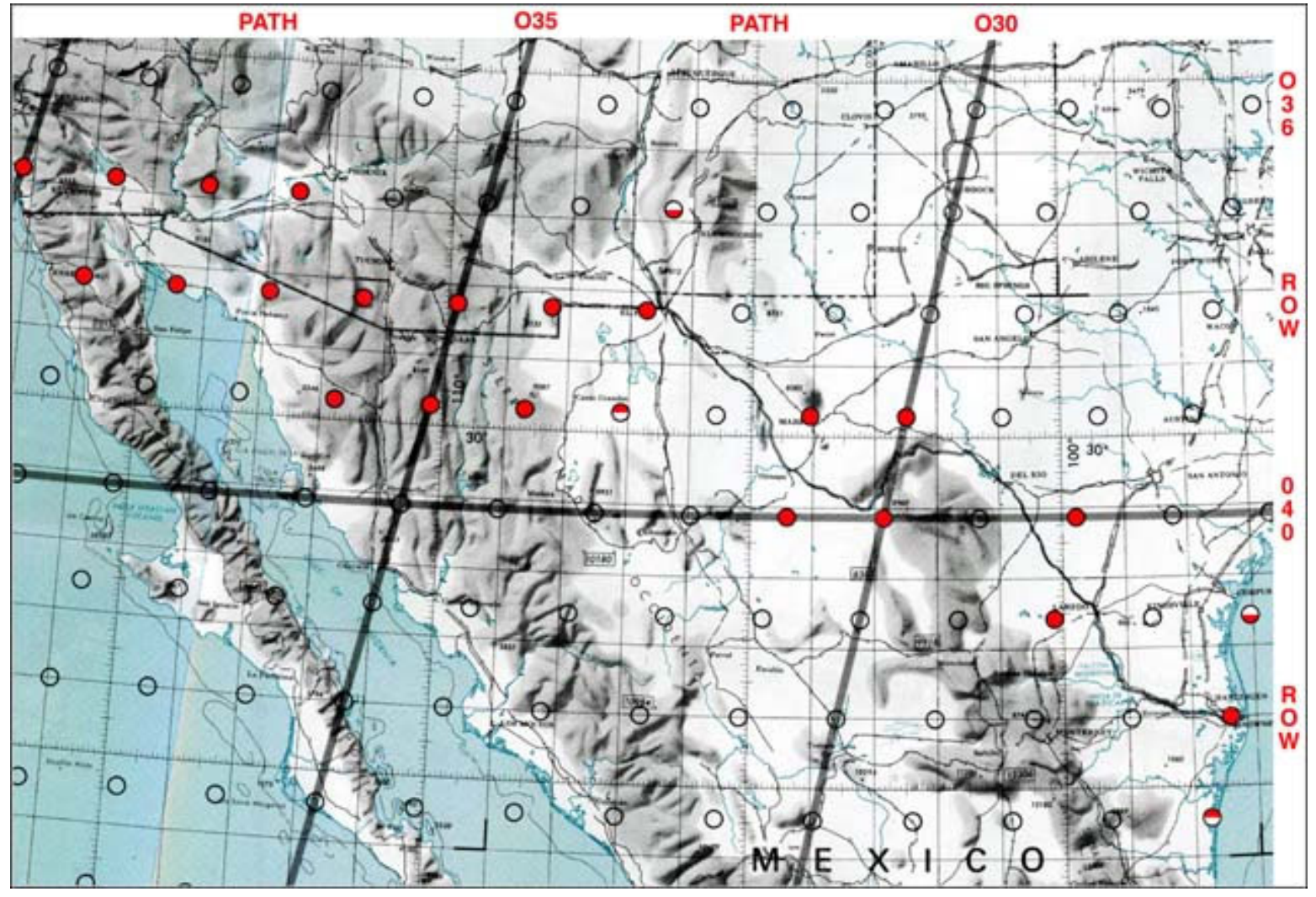

Figure 2. Approximate locations of the centers of the TM scenes

The approximate locations of the centers of the TM scenes are indicated in Figure 2 above. Scenes indicated with a red circle are included in this dataset. Half filled circles indicate scenes shifted from the normal scene center. 
Table 1. Landsat TM scenes of the Borderlands region

(* scenes shifted south $20 \%$ to $60 \%$ )

\begin{tabular}{|c|c|c|c|c|c|c|}
\hline PATH & $\begin{array}{l}\text { ROW } \\
*\end{array}$ & SHIFT & DATE & AREA & SCENE ID & $\begin{array}{l}\text { UTM } \\
\text { ZONE }\end{array}$ \\
\hline $\begin{array}{l}\text { Image } \\
\text { files } \\
\text { included } \\
\text { on CD 1 } \\
\end{array}$ & & & & EASTERN BORDER & & \\
\hline 26 & 41 & $(50 \%)$ & $\begin{array}{l}11 / 28 / 8 \\
4\end{array}$ & Corpus Cristi & LT5026040008433310 & 14 \\
\hline 26 & 42 & $(50 \%)$ & $\begin{array}{l}11 / 28 / 8 \\
4\end{array}$ & Brownsville & LT5026041008433310 & 14 \\
\hline 28 & 40 & $(20 \%)$ & $7 / 14 / 94$ & Monterrey & LT5028040009419510 & 14 \\
\hline 28 & 41 & $(20 \%)$ & $7 / 14 / 94$ & Monterrey & LT5028041009419510 & 14 \\
\hline 30 & 39 & & $4 / 20 / 86$ & Big Bend (E) & LT5030039008611010 & 13 \\
\hline 30 & 40 & & $4 / 20 / 86$ & Big Bend (E) & LT5030040008611010 & 13 \\
\hline 31 & 39 & & $4 / 14 / 87$ & Big Bend (W) & LT5031039008710410 & 13 \\
\hline 31 & 40 & & $5 / 2 / 88$ & Big Bend (W) & LT5031040008812310 & 13 \\
\hline $\begin{array}{l}\text { Image } \\
\text { files } \\
\text { included } \\
\text { on CD } 2\end{array}$ & & & & CENTRAL BORDER & & \\
\hline 33 & 37 & $(60 \%)$ & $5 / 6 / 96$ & El Paso-Ciudad Juarez & LT5033037009615810 & 13 \\
\hline 33 & 38 & $(60 \%)$ & $5 / 6 / 96$ & El Paso-Juarez & LT5033038009615810 & 13 \\
\hline 34 & 38 & & $6 / 13 / 84$ & SW New Mexico & LT5034038008416510 & 13 \\
\hline 34 & 39 & & $11 / 4 / 84$ & NW Chihuahua & LT5034039008430910 & 12 \\
\hline 35 & 38 & & $6 / 20 / 84$ & SE Arizona (Sierra Vista) & LT5035038008417210 & 12 \\
\hline 35 & 38 & & $6 / 24 / 97$ & SE Arizona (Sierra Vista) & LT5035038009717510 & 12 \\
\hline 35 & 39 & & $6 / 24 / 97$ & NE Sonora (Cananea) & LT5035039009717510 & 12 \\
\hline 36 & 38 & & $10 / 2 / 96$ & Tucson - Nogales & LT5036038009627610 & 12 \\
\hline $\begin{array}{l}\text { Image } \\
\text { files } \\
\text { included } \\
\text { on CD 3 }\end{array}$ & & & & WESTERN BORDER & & \\
\hline 36 & 39 & & $10 / 2 / 96$ & NW Sonora & LT5036039009627610 & 12 \\
\hline 37 & 37 & $(60 \%)$ & $5 / 10 / 93$ & Southcentral Arizona (Ajo) & LT5037037009313010 & 12 \\
\hline 37 & 38 & & $6 / 18 / 84$ & Pinacate & LT5037038008417010 & 12 \\
\hline 38 & 37 & & $5 / 2 / 92$ & SW Arizona (Yuma) & LT5037038009212310 & 11 \\
\hline 38 & 38 & & $12 / 6 / 91$ & Colorado River Delta & LT5038038009134010 & 11 \\
\hline 39 & 37 & & $1 / 14 / 92$ & Salton Sea - Mexicali & LT5039037009201410 & 11 \\
\hline 39 & 38 & & $\begin{array}{l}10 / 23 / 9 \\
0\end{array}$ & Baja California Norte & LT5039038009029610 & 11 \\
\hline 40 & 37 & & $12 / 3 / 82$ & San Diego - Tijuana & LT4040037008233710 & 11 \\
\hline
\end{tabular}


The Landsat 5 satellite has a circular, near-polar orbit with a repeat cycle of 16 days and a nominal altitude of $705.3 \mathrm{~km}$ (438 miles). Each orbit takes 98.9 minutes. The orbit is sunsynchronous and is timed so that the satellite passes over the equator at 9:37 AM local mean sun time on the daylight (north to south) portion of each orbital pass. Image data for the Borderlands region are collected by the Landsat 5 at about 9:30 AM mean local sun time.

Landsat 5's Thematic Mapper scanner collects data in a continuous stream along a 185-km (115 mile) wide path as the satellite moves from north to south along the daylight portion of its orbit. The TM scanner measures light intensity in the visible and infrared parts of the electromagnetic spectrum. Measurements are collected from seven broad spectral bands (Table 2), three nearly contiguous bands spanning most of the visible part of the spectrum (Bands 1,2 and 3) and four more widely spaced bands covering critical portions of the infrared spectrum (Bands 4 through 7).

Table 2. Characteristics of the seven Landsat Thematic Mapper spectral bands

BAND

1

2

3

4

5

6 7
WAVELENGTH

$0.45-0.52$ (visible blue)

$0.52-0.60$ (visible green)

$0.63-0.69$ (visible red)

$0.76-0.90$ (near infrared)

1.55 - 1.75 (middle infrared)

10.4 - 12.5 (thermal infrared)

2.08 - 2.35 (middle infrared)

\section{CHARACTERISTICS}

maximum water penetration; minimum atmospheric haze penetration; high reflectivity from clay

relatively high reflectivity from chlorophyll (living vegetation)

low reflectivity from chlorophyll (living vegetation); high reflectivity form ferrous iron oxide

high reflectivity from chlorophyll (living vegetation); very low penetration or reflectivity from water

discrimination of soil and vegetation moisture; very low penetration or reflectivity from water

thermal mapping; discrimination of soil moisture

discrimination of rock types including carbonates, clays and hydrothermal alteration

The Landsat TM images included on these CD-ROMs are digital color composites of middle, near infrared and visible light derived from TM bands 7, 4 and 2. Although the infrared portion of the electromagnetic spectrum lies beyond the range of human eyesight (and therefore commonly emphasizes features that are invisible to the human eye), this combination of infrared and visible light generally produces a quite natural looking image. Vegetation appears as various shades of green and yellow green, rocks and soils commonly appear as shades of dark red to yellow brown and blue-gray to gray, water appears as dark blue, and man-made features appear 
as shades of purple, gray and blue-gray. However, these color relations are only generally valid. Each data pixel is the summation of light reflected from all of the materials covering the surface of the area represented by that pixel (almost $10,000 \mathrm{ft}^{2}$ ). These materials may include growing vegetation, leaf litter, bare soil, rock outcrops, and man-made structures. Variable soil moisture and shadows also add to the complexity of the signal. What is represented on the image is the average of all of these effects so that there is no simple conversion of image colors to surface materials.

\section{File Specifications}

Format: JPEG, using minimum compression, RGB color

Orientation: Map orientation

Projection: Universal Transverse Mercator

Pixel size: 28.5 by 28.5 meters (resampled by cubic convolution from 30 by 30 meters)

Processing: Each image file has been enhanced for final viewing and (or) printing (including contrast stretching, saturation enhancement, and image sharpening)

\section{Image Characteristics}

Projection: The Landsat TM full-scene images provided on the Borderlands CD-ROMs have been projected to the standard Universal Transverse Mercator (UTM) grid. UTM zone varies according to the location of the image.

Orientation: The Landsat TM full-scene images provided on the Borderlands CD-ROMs have been rotated to a standard map orientation (i.e. The 'top' of each image is oriented north).

Scale: The Landsat TM full-scene images provided on the Borderlands CD-ROMs are full resolution images. Pixel size for each image is 28.5 X 28.5 meters. Changing the number of pixels per $\mathrm{cm}$ (or inch) on the display or print can vary the display or print scale of these images. For example: (1) a display or print resolution of 35.087 pixels per $\mathrm{cm}$ is equivalent to a scale of $1: 100,000$ (1000 $\mathrm{m}$ per $\mathrm{cm})$; (2) a display or print resolution of 87.7175 pixels per $\mathrm{cm}$ is equivalent to a scale of $1: 250,000(2500 \mathrm{~m}$ per $\mathrm{cm})$ etc.

\section{GEOREGISTRATION PROCEDURE FOR LANDSAT TM IMAGES OF THE BORDERLANDS REGION}

\section{Image Registration}

The characteristics of the Landsat TM Borderlands images were selected to facilitate coregistration with standard UTM projected map data. A "world" file containing georeference information has been provided for most images. These files have a ".jgw" file name extension and are recognized by several GIS software packages. This extension allows the image to open directly in the GIS in the proper geospatial orientation (UTM projection only). If your software does not recognize the "world" file, these images can be coregistered in two simple steps: (1) adjusting either the image or map scale so that the image scale equals the map scale; and (2) performing a simple $\mathrm{X}-\mathrm{Y}$ shift of either image or map to achieve coregistration. 
To facilitate further coregistration of those images located at least partly within the United States, three sets of files are included on each CD-ROM:

(1) The standard U.S. Geological Survey Eros Data Center (NLAPS) metadata files (.TXT format) for each image. These files document the pixel size, image orientation, map projection parameters, and nominal coordinates (latitude-longitude) for the corner points and center point of each image.

(2) Full-resolution location images (500 X 500 pixels in size) showing the exact positions of easily-identified reference locations on each Landsat TM scene. At least 4 reference locations (and location images) are provided for each Landsat TM scene that is located at least partly within the United States. On each location image, the exact position of the reference location is marked with a red cross.

(3) A reference location table (MS Word format) listing the latitude and longitude of each reference location with a nominal precision of 0.001 minute of arc.

\section{Procedure for Image Registration}

(1) Open (display) the Landsat TM scene to be registered.

(2) Open (display) the reference location images for that scene.

(3) Locate the precise reference locations on the Landsat TM scene by visual comparison with the reference location images.

(4) Refer to the reference location table to determine the latitude and longitude for each reference location.

(5) Use the reference location positions and latitude-longitude coordinates to register the Landsat TM scene.

$\begin{array}{lllll}\text { PAT } & \text { ROW } & \text { LOCATION } & \text { LATITUDE }(\mathrm{N}) & \text { LONGITUDE }(\mathrm{W}) \\ 26 & 41 & 1 & 27^{\circ} 48.712^{\prime} & 97^{\circ} 23.748^{\prime} \\ & & 2 & 27^{\circ} 30.474^{\prime} & 97^{\circ} 48.501^{\prime} \\ & & 3 & 26^{\circ} 29.444^{\prime} & 97^{\circ} 54.774^{\prime} \\ & & 4 & 26^{\circ} 56.080^{\prime} & 97^{\circ} 28.241^{\prime} \\ & & 5 & 28^{\circ} 01.023^{\prime} & 97^{\circ} 10.388^{\prime} \\ & & & & \\ & 42 & 1 & 26^{\circ} 04.694 & 97^{\circ} 12.348^{\prime} \\ & & 2 & 26^{\circ} 11.902^{\prime} & 98^{\circ} 12.190^{\prime} \\ & & 2 \mathrm{a} & 26^{\circ} 08.886^{\prime} & 98^{\circ} 04.524^{\prime} \\ & & 3 & 26^{\circ} 19.212^{\prime} & 97^{\circ} 27.267^{\prime} \\ & & 4 & 26^{\circ} 29.984^{\prime} & 98^{\circ} 02.911^{\prime}\end{array}$




\begin{tabular}{|c|c|c|c|c|}
\hline \multirow[t]{5}{*}{28} & 40 & 1 & $28^{\circ} 42.546^{\prime}$ & $100^{\circ} 28.156^{\prime}$ \\
\hline & & 2 & $28^{\circ} 10.847^{\prime}$ & $100^{\circ} 04.783^{\prime}$ \\
\hline & & 3 & $29^{\circ} 14.026^{\prime}$ & $99^{\circ} 47.579^{\prime}$ \\
\hline & & 4 & $28^{\circ} 26.635^{\prime}$ & $99^{\circ} 14.952^{\prime}$ \\
\hline & & 5 & $27^{\circ} 45.900^{\prime}$ & $99^{\circ} 26.000^{\prime}$ \\
\hline \multirow[t]{7}{*}{30} & 39 & 1 & $30^{\circ} 55.855^{\prime}$ & $103^{\circ} 04.880^{\prime}$ \\
\hline & & 2 & $30^{\circ} 54.030^{\prime}$ & $103^{\circ} 03.317^{\prime}$ \\
\hline & & 3 & $30^{\circ} 12.375^{\prime}$ & $103^{\circ} 10.924^{\prime}$ \\
\hline & & 4 & $29^{\circ} 35.966^{\prime}$ & $103^{\circ} 08.578^{\prime}$ \\
\hline & & 5 & $29^{\circ} 54.220^{\prime}$ & $101^{\circ} 48.325^{\prime}$ \\
\hline & & 6 & $29^{\circ} 48.083^{\prime}$ & $101^{\circ} 48.318^{\prime}$ \\
\hline & & 7 & $30^{\circ} 43.683^{\prime}$ & $101^{\circ} 33.327^{\prime}$ \\
\hline \multirow[t]{5}{*}{30} & 40 & 1 & $29^{\circ} 35.966^{\prime}$ & $103^{\circ} 08.578^{\prime}$ \\
\hline & & 2 & $29^{\circ} 10.415^{\prime}$ & $102^{\circ} 57.041^{\prime}$ \\
\hline & & 3 & $29^{\circ} 08.900^{\prime}$ & $103^{\circ} 00.500^{\prime}$ \\
\hline & & 4 & $29^{\circ} 07.275^{\prime}$ & $103^{\circ} 31.470^{\prime}$ \\
\hline & & 5 & $29^{\circ} 48.266^{\prime}$ & $103^{\circ} 34.574^{\prime}$ \\
\hline \multirow[t]{7}{*}{31} & 39 & 1 & $30^{\circ} 55.855^{\prime}$ & $103^{\circ} 04.880^{\prime}$ \\
\hline & & 2 & $30^{\circ} 54.030^{\prime}$ & $103^{\circ} 03.317^{\prime}$ \\
\hline & & 3 & $30^{\circ} 23.218^{\prime}$ & $103^{\circ} 40.888^{\prime}$ \\
\hline & & 4 & $30^{\circ} 12.375^{\prime}$ & $103^{\circ} 10.924^{\prime}$ \\
\hline & & 5 & $30^{\circ} 22.178^{\prime}$ & $104^{\circ} 00.954^{\prime}$ \\
\hline & & 6 & $29^{\circ} 58.984^{\prime}$ & $104^{\circ} 40.805^{\prime}$ \\
\hline & & 7 & $31^{\circ} 03.712^{\prime}$ & $104^{\circ} 46.947^{\prime}$ \\
\hline \multirow[t]{5}{*}{33} & 40 & 1 & $32^{\circ} 20.877^{\prime}$ & $106^{\circ} 46.187^{\prime}$ \\
\hline & & 2 & $32^{\circ} 52.469^{\prime}$ & $105^{\circ} 57.855^{\prime}$ \\
\hline & & 3 & $32^{\circ} 14.384^{\prime}$ & $107^{\circ} 22.666^{\prime}$ \\
\hline & & 4 & $32^{\circ} 52.764^{\prime}$ & $107^{\circ} 17.837^{\prime}$ \\
\hline & & 5 & $31^{\circ} 31.173^{\prime}$ & $106^{\circ} 07.867^{\prime}$ \\
\hline \multirow[t]{6}{*}{34} & 38 & 1 & $32^{\circ} 14.253^{\prime}$ & $108^{\circ} 57.248^{\prime}$ \\
\hline & & 2 & $31^{\circ} 52.248^{\prime}$ & $109^{\circ} 02.120^{\prime}$ \\
\hline & & 3 & $32^{\circ} 22.904^{\prime}$ & $108^{\circ} 42.496^{\prime}$ \\
\hline & & 4 & $32^{\circ} 17.335^{\prime}$ & $107^{\circ} 45.656^{\prime}$ \\
\hline & & 5 & $31^{\circ} 49.693^{\prime}$ & $107^{\circ} 38.437^{\prime}$ \\
\hline & & 6 & $31^{\circ} 22.585^{\prime}$ & $109^{\circ} 12.680^{\prime}$ \\
\hline
\end{tabular}




\begin{tabular}{|c|c|c|c|c|}
\hline \multirow[t]{8}{*}{35} & 38 & 1 & $31^{\circ} 58.280^{\prime}$ & $110^{\circ} 19.660^{\prime}$ \\
\hline & & 2 & $31^{\circ} 58.574^{\prime}$ & $110^{\circ} 19.004^{\prime}$ \\
\hline & & 3 & $31^{\circ} 40.772^{\prime}$ & $110^{\circ} 39.354^{\prime}$ \\
\hline & & 4 & $31^{\circ} 22.807^{\prime}$ & $110^{\circ} 12.423^{\prime}$ \\
\hline & & 5 & $31^{\circ} 43.408$ & $110^{\circ} 11.615^{\prime}$ \\
\hline & & 6 & $32^{\circ} 14.253^{\prime}$ & $108^{\circ} 57.248^{\prime}$ \\
\hline & & 7 & $31^{\circ} 52.245^{\prime}$ & $109^{\circ} 02.112^{\prime}$ \\
\hline & & 8 & $31^{\circ} 21.142^{\prime}$ & $109^{\circ} 34.770^{\prime}$ \\
\hline \multirow[t]{7}{*}{36} & 38 & 1 & $32^{\circ} 04.613^{\prime}$ & $111^{\circ} 18.714^{\prime}$ \\
\hline & & 2 & $31^{\circ} 55.269^{\prime}$ & $111^{\circ} 53.394^{\prime}$ \\
\hline & & 3 & $31^{\circ} 25.818^{\prime}$ & $110^{\circ} 57.891^{\prime}$ \\
\hline & & 4 & $31^{\circ} 40.766^{\prime}$ & $110^{\circ} 39.346^{\prime}$ \\
\hline & & 5 & $32^{\circ} 22.853^{\prime}$ & $111^{\circ} 10.188^{\prime}$ \\
\hline & & 6 & $31^{\circ} 58.280^{\prime}$ & $110^{\circ} 19.660^{\prime}$ \\
\hline & & 7 & $31^{\circ} 58.574^{\prime}$ & $110^{\circ} 19.004^{\prime}$ \\
\hline \multirow[t]{8}{*}{37} & 38 & 1 & $31^{\circ} 52.817^{\prime}$ & $112^{\circ} 49.035^{\prime}$ \\
\hline & & 2 & $32^{\circ} 16.068^{\prime}$ & $112^{\circ} 44.342^{\prime}$ \\
\hline & & 3 & $32^{\circ} 56.397^{\prime}$ & $112^{\circ} 44.050^{\prime}$ \\
\hline & & 4 & $32^{\circ} 09.593^{\prime}$ & $112^{\circ} 06.696^{\prime}$ \\
\hline & & 5 & $32^{\circ} 48.040^{\prime}$ & $113^{\circ} 32.453^{\prime}$ \\
\hline & & 6 & $31^{\circ} 48.267^{\prime}$ & $112^{\circ} 18.092^{\prime}$ \\
\hline & & 7 & $32^{\circ} 45.778^{\prime}$ & $111^{\circ} 45.442^{\prime}$ \\
\hline & & 8 & $32^{\circ} 27.180^{\prime}$ & $112^{\circ} 51.708^{\prime}$ \\
\hline \multirow[t]{9}{*}{38} & 37 & 1 & $33^{\circ} 05.141^{\prime}$ & $114^{\circ} 54.663^{\prime}$ \\
\hline & & 2 & $32^{\circ} 59.857^{\prime}$ & $115^{\circ} 04.254^{\prime}$ \\
\hline & & 3 & $32^{\circ} 43.706^{\prime}$ & $114^{\circ} 37.117^{\prime}$ \\
\hline & & 4 & $32^{\circ} 45.667^{\prime}$ & $114^{\circ} 24.743^{\prime}$ \\
\hline & & 5 & $32^{\circ} 46.286^{\prime}$ & $114^{\circ} 23.333^{\prime}$ \\
\hline & & 6 & $32^{\circ} 41.618^{\prime}$ & $113^{\circ} 57.196^{\prime}$ \\
\hline & & 7 & $32^{\circ} 48.040^{\prime}$ & $113^{\circ} 32.453^{\prime}$ \\
\hline & & 8 & $33^{\circ} 36.276^{\prime}$ & $114^{\circ} 31.854^{\prime}$ \\
\hline & & 9 & $33^{\circ} 43.404^{\prime}$ & $113^{\circ} 42.161^{\prime}$ \\
\hline \multirow[t]{5}{*}{38} & 38 & 1 & $32^{\circ} 30.967^{\prime}$ & $114^{\circ} 45.909^{\prime}$ \\
\hline & & 2 & $32^{\circ} 35.780^{\prime}$ & $114^{\circ} 45.646^{\prime}$ \\
\hline & & 3 & $32^{\circ} 30.660^{\prime}$ & $114^{\circ} 41.904^{\prime}$ \\
\hline & & 4 & $32^{\circ} 23.701^{\prime}$ & $114^{\circ} 06.377^{\prime}$ \\
\hline & & 5 & $32^{\circ} 16.746^{\prime}$ & $113^{\circ} 52.574^{\prime}$ \\
\hline \multirow[t]{5}{*}{39} & 37 & 1 & $32^{\circ} 59.857^{\prime}$ & $115^{\circ} 04.254^{\prime}$ \\
\hline & & 2 & $33^{\circ} 42.619^{\prime}$ & $115^{\circ} 24.017^{\prime}$ \\
\hline & & 3 & $33^{\circ} 07.545^{\prime}$ & $115^{\circ} 51.312^{\prime}$ \\
\hline & & 4 & $32^{\circ} 44.040^{\prime}$ & $115^{\circ} 59.641^{\prime}$ \\
\hline & & 5 & $33^{\circ} 41.369^{\prime}$ & $116^{\circ} 24.156^{\prime}$ \\
\hline
\end{tabular}


40

37
2
3
4
5
6
7
8

$32^{\circ} 36.596^{\prime}$

$32^{\circ} 34.978^{\prime}$

$32^{\circ} 45.573^{\prime}$

$32^{\circ} 44.055^{\prime}$

$33^{\circ} 44.875^{\prime}$

$33^{\circ} 15.390^{\prime}$

$33^{\circ} 27.513^{\prime}$

$33^{\circ} 29.389^{\prime}$

$116^{\circ} 41.859^{\prime}$

$116^{\circ} 37.220^{\prime}$

$116^{\circ} 29.124^{\prime}$

$116^{\circ} 28.793^{\prime}$

$116^{\circ} 53.925^{\prime}$

$116^{\circ} 22.495^{\prime}$

$117^{\circ} 41.471^{\prime}$

$117^{\circ} 39.970^{\prime}$

\section{BIBLIOGRAPHY}

U.S. Environmental Protection Agency, 1996, U.S./México Border XXI Program Framework Document: U.S. Environmental Protection Agency Report, EPA 160-R-96-003 [Variously Paged] 


\section{METADATA FOR THEMATIC MAPPER IMAGES}

Identification_Information:

Citation:

Citation_Information:

Originator: U.S. Geological Survey (USGS) EROS Data Center (EDC

Publication_Date: 2000

Title: Processed Thematic Mapper satellite imagery for selected areas within the U.S.-Mexico borderlands

Geospatial_Data_Presentation_Form: remote-sensing image

Publication_Information:

Publication_Place: Menlo Park, CA

Publisher: U.S. Geological Survey

Description:

Abstract: The passage of the North American Trade Agreement (NAFTA), establishment of the Border Environmental Cooperation Commission as well as the EPA U.S./Mexico Border XXI Program has focused attention to the environmental social-cultural, and economic conditions in the United States-Mexico frontier and to the enhanced necessity of a binational, transborder approach in addressing problems. Towards this end, this U.S.-Mexico borderlands Thematic Mapper selection is designed to be utilized as fundamental part of a basic geographic information system database for natural resource, environmental, and land-management studies.

Purpose: To provide processed satellite images of key areas along the U.S.-Mexico border for use in a broad spectrum of studies. Landsat data have been used by government, commercial, industrial, civilian, and educational communities in the U.S. and worldwide. They are being used to support a wide range of applications in such areas as global change research, agriculture, forestry, geology, resources management, geography, mapping, water quality, and oceanography. Landsat data have potential applications for monitoring the conditions of the Earth's land surface

Time_Period_of_Content:

Time_Period_Information:

Range_of_Dates/Times:

Beginning_Date: 1984

Ending_Date: 1997

Currentness_Reference: ground condition 
Status:

Progress: complete

Maintenance_and_Update_Frequency: None

Spatial_Domain:

Bounding_Coordinates:

West_Bounding_Coordinate: 118.00

East_Bounding_Coordinate: 97.00

North_Bounding_Coordinate: 34.00

South_Bounding_Coordinate: 27.00

Keywords:

Theme:

Theme_Keyword_Thesaurus: GCMD Parameter Keywords

Theme_Keyword: EARTH SCIENCE

Theme_Keyword: RADIANCE OR IMAGERY

Theme_Keyword: INFRARED WAVELENGTHS

Theme_Keyword: INFRARED IMAGERY

Theme_Keyword: VISIBLE WAVELENGTHS

Theme_Keyword: VISIBLE IMAGERY

Theme_Keyword: DAAC

Theme_Keyword: EDC

Theme_Keyword: EROS

Theme_Keyword: IMAGERY

Theme_Keyword: LANDSAT

Theme_Keyword: RADIANCE

Theme_Keyword: REMOTE SENSING

Theme_Keyword: SATELLITE

Theme_Keyword: SPACE IMAGING EOSAT 
Theme_Keyword: THEMATIC MAPPER

Theme_Keyword: TM

Theme_Keyword: USGS

Place:

Place_Keyword_Thesaurus: GCMD Location Keywords

Place_Keyword: NORTH AMERICA

Access_Constraints: none

Use_Constraints: none

Point_of_Contact:

Contact_Information:

Contact_Person_Primary:

Contact_Person: Floyd Gray

Contact_Organization: U.S. Geological Survey

Contact_Position: Technical Contact

Contact_Address:

Address_Type: mailing and physical address

Address: ENR Building, 520 N Park Ave

City: Tucson

State_or_Province: AZ

Postal_Code: 85719-5035

Country: USA

Contact_Voice_Telephone: 520-670-5582

Contact_Electronic_Mail_Address: fgray@usgs.gov

Contact_Instructions: None

Security_Information:

Security_Classification_System: None

Security_Classification: Unclassified 
Security_Handling_Description: None

Native_Data_Set_Environment: UNIX and PC

Cross_Reference:

Citation_Information:

Originator: U.S. Geological Survey

Publication_Date: 2000

Title: Land Satellite (LANDSAT) Multispectral Scanner (MSS)

Geospatial_Data_Presentation_Form: remote-sensing image

Publication_Information:

Publication_Place: Sioux Falls, SD

Publisher: U.S. Geological Survey

Other_Citation_Details: The concept of a civilian Earth resources satellite was conceived in the Department of Interior in the mid-1960's. The National Aeronautics and Space Administration (NASA) embarked on an initiative to develop and launch the first Earth monitoring satellite to meet the needs of resource managers and Earth scientists. The USGS entered into a partnership with NASA in the early 1970's to assume responsibility for the archive management and distribution of Landsat data products. On July 23, 1972, NASA launched the first in a series of satellites designed to provide repetitive global coverage of the Earth's land masses.

Online_Linkage: <URL:http://edc.usgs.gov/nsdi/landsat_mss/ph1crit.htm>

Cross_Reference:

Citation_Information:

Originator: U.S. Geological Survey EROS Data Center

Publication_Date: 1972

Title: LGSOWG Landsat Multispectral Scanner (MSS) Imagery

Edition: 1.0

Geospatial_Data_Presentation_Form: remote-sensing image

Publication_Information:

Publication_Place: Sioux Falls SD

Publisher: U.S. Geological Survey

Other_Citation_Details: The Global Land Information System (GLIS) and the EOSDIS 
Information Management System (IMS) are interactive query systems providing information on this data set.

Online_Linkage: URL:http://edc.usgs.gov/Webglis/glisbin/guide.pl/glis/hyper/guide/lgsowg mss

Data_Quality_Information:

Attribute_Accuracy:

Attribute_Accuracy_Report: The identification of features is provided by the distinct electromagnetic energy it emits, reflects, or otherwise transmits. This is called the spectral signature. Other signatures are tone (lightness or darkness), texture (surface roughness or smoothness), pattern, shadow, shape and size are as important. Thus, through the use of Thematic Mapper, such elements as water features, soils, and vegetation can be identified and distinguished from each other. The wavelength range for the TM sensor is from the visible (blue), through the mid-IR, into the thermal-IR portion of the electromagnetic spectrum. Sixteen detectors for the visible and mid-IR wavelength bands in the TM sensor provide 16 scan lines on each active scan. Four detectors for the thermal-IR band provide four scan lines on each active scan. The TM sensor has a spatial resolution of $30 \mathrm{~m}$ for the visible, near-IR, and mid-IR wavelengths and a spatial resolution of $120 \mathrm{~m}$ for the thermal-IR band.

Logical_Consistency_Report: All of the Landsats have been in sun-synchronous orbits with equatorial crossing times ranging from 8:30 a.m. for Landsat 1, 9 a.m. for Landsat 2, to 9:45 a.m. for Landsat 5. The Landsat system provides for global data between 81 degrees north latitude and 81 degrees south latitude.

Completeness_Report: Images provided by this report cover selected areas of the U.S.-Mexico border zone.

Horizontal_Positional_Accuracy:

Horizontal_Positional_Accuracy_Report: The TM sensor has a spatial resolution of 30 meters for the visible, near-IR, and mid-IR wavelengths and a spatial resolution of 120 meters for the thermal-IR band.

Lineage:

Source_Information:

Source_Citation:

Citation_Information:

Originator: U.S. Geological Survey

Publication_Date: 19720101

Title: Land Satellite Multispectral Scanner (Landsat MSS)

Geospatial_Data_Presentation_Form: Remote-sensing image 
Publication_Information:

Publication_Place: Sioux Falls, SD

Publisher: U.S. Geological Survey

Other_Citation_Details: Earth scientists. The USGS entered into a partnership with NASA in the early 1970's to assume responsibility for the archive management and distribution of Landsat data products. On July 23, 1972, NASA launched the first in a series of satellites designed to provide repetitive global coverage of the Earth's land masses. Designated initially as the Earth Resources Technology Satellite-A (ERTS-A), it used a Nimbus-type platform that was modified to carry sensor systems and data relay equipment. When operational orbit was achieved, it was designated ERTS-1. The satellite continued to function beyond its designed life expectancy of 1 year and finally ceased to operate on January 6, 1978, more than 5 years after its launch date. The second in this series of Earth resources satellites (designated ERTS-B) was launched January 22, 1975. It was renamed Landsat 2 by NASA, which also renamed ERTS- 1 to Landsat 1. Three additional Landsats were launched in 1978, 1982, and 1984 (Landsats 3, 4, and 5 respectively). Each successive satellite system had improved sensor and communications capabilities.

Online_Linkage: <URL: http://edc.usgs.gov/glis/glis.html> or

$<$ URL:http://edc.usgs.gov/landdaac/landdaac.html>

Type_of_Source_Media: cartridge tape

Source_Time_Period_of_Content:

Time_Period_Information:

Range_of_Dates/Times:

Beginning_Date: 19820716

Ending_Date: Present

Source_Currentness_Reference: ground condition

Source_Citation_Abbreviation: digital

Source_Contribution: Remote sensing imagery along with ancillary data.

Process_Step:

Process_Description: These images were processed on a Macintosh computer in Adobe Photoshop. Band selection and color balance were chosen to provide images useful for a broad spectrum of application.

Source_Used_Citation_Abbreviation: TM

Process_Date: 1999 
Source_Produced_Citation_Abbreviation: Landsat MSS

Spatial_Data_Organization_Information:

Indirect_Spatial_Reference: A Landsat 4 and 5 TM scene has an instantaneous field of view (IFOV) of 30 square meters in bands 1 through 5 and band 7, band 6 has an IFOV of 120 square meters on the ground. The resolution for the TM sensor is shown below: Landsats 4-5 Resolution (meters) Band 130 Band 230 Band 330 Band 430 Band 530 Band 6120 Band 730

Direct_Spatial_Reference_Method: Raster

Raster_Object_Information:

Raster_Object_Type: Pixel

Entity_and_Attribute_Information:

Overview_Description:

Entity_and_Attribute_Overview: These processed Landsat satellite images provide highresolution multispectral coverage of selected areas. The characteristics of the MSS and TM bands were selected to maximize their capabilities for detecting and monitoring different types of Earth resources. For example, TM band 2 can detect green reflectance from healthy vegetation, and band 3 of TM is designed for detecting chlorophyll absorption in vegetation. TM band 4 is ideal for near-IR reflectance peaks in healthy green vegetation and for detecting water-land interfaces. Wavelength of TM band 1 can penetrate water for bathymetric mapping along coastal areas and is useful for soil-vegetation differentiation and for distinguishing forest types. The two mid-IR red bands on TM (bands 5 and 7) are useful for vegetation and soil moisture studies, and discriminating between rock and mineral types. The thermal-IR band on TM (band 6) is designed to assist in thermal mapping, and for soil moisture and vegetation studies. TM Bands 7, 4, and 2 have been combined to make false-color composite images. This band combination makes vegetation appear as shades of red, brighter reds indicating more vigorously growing vegetation. Soils with no or sparse vegetation will range from white (sands) to greens or browns depending on moisture and organic matter content. Water bodies will appear blue. Deep, clear water will be dark blue to black in color, while sediment-laden or shallow waters will appear lighter in color. Urban areas will appear blue-gray in color. Clouds and snow will be bright white. They are usually distinguishable from each other by the shadows associated with the clouds. Exposed bedrock will appear in a wide range of colors depending on the composition and other factors.

Entity_and_Attribute_Detail_Citation: U.S. Department of the Interior, 1992, Department of the Interior, United States Geological Survey.

Distribution_Information:

Distributor:

Contact_Information:

Contact_Organization_Primary: 
Contact_Organization: U.S. Geological Survey

Contact_Position: Customer Services Representative

Contact_Address:

Address_Type: mailing and physical address

Address: Open-File Reports, Box 252

City: Denver

State_or_Province: CO

Postal_Code: 80225

Country: USA

Contact_Voice_Telephone: 303-202-4200

Contact_Facsimile_Telephone: 303-202-4695

Contact_Instructions: None

Resource_Description: OF Report 00-309

Distribution_Liability: Although these data have been processed successfully on a computer system at the U.S. Geological Survey, U.S. Department of the Interior, no warranty expressed or implied is made by the Geological Survey regarding the utility of the data on any other system, nor shall the act of distribution constitute any such warranty. The Geological Survey will warrant the delivery of this product in computer-readable format. and will offer appropriate adjustment of credit when the product is determined unreadable by correctly adjusted computer input peripherals, or when the physical medium is delivered in damaged condition. Requests for adjustments of credit must be made within 90 days from the date of this shipment from the ordering site.

Metadata_Reference_Information:

Metadata_Date: 19991000

Metadata_Review_Date: 20000421

Metadata_Contact:

Contact_Information:

Contact_Organization_Primary:

Contact_Organization: U.S. Geological Survey

Contact_Person: Robert Miller 
Contact_Address:

Address_Type: mailing and physical address

Address: U.S. Geological Survey, MS 901

City: Menlo Park

State_or_Province: CA

Postal_Code: 94025

Country: USA

Contact_Voice_Telephone: 650 329-5407

Contact_Instructions: None

Metadata_Standard_Name: Content Standards for Digital Geospatial Metadata

Metadata_Standard_Version: 1.0

Metadata_Time_Convention: local time

Metadata_Access_Constraints: None

Metadata_Use_Constraints: None

Metadata_Security_Information:

Metadata_Security_Classification_System: None

Metadata_Security_Classification: Unclassified

Metadata_Security_Handling_Description: None 




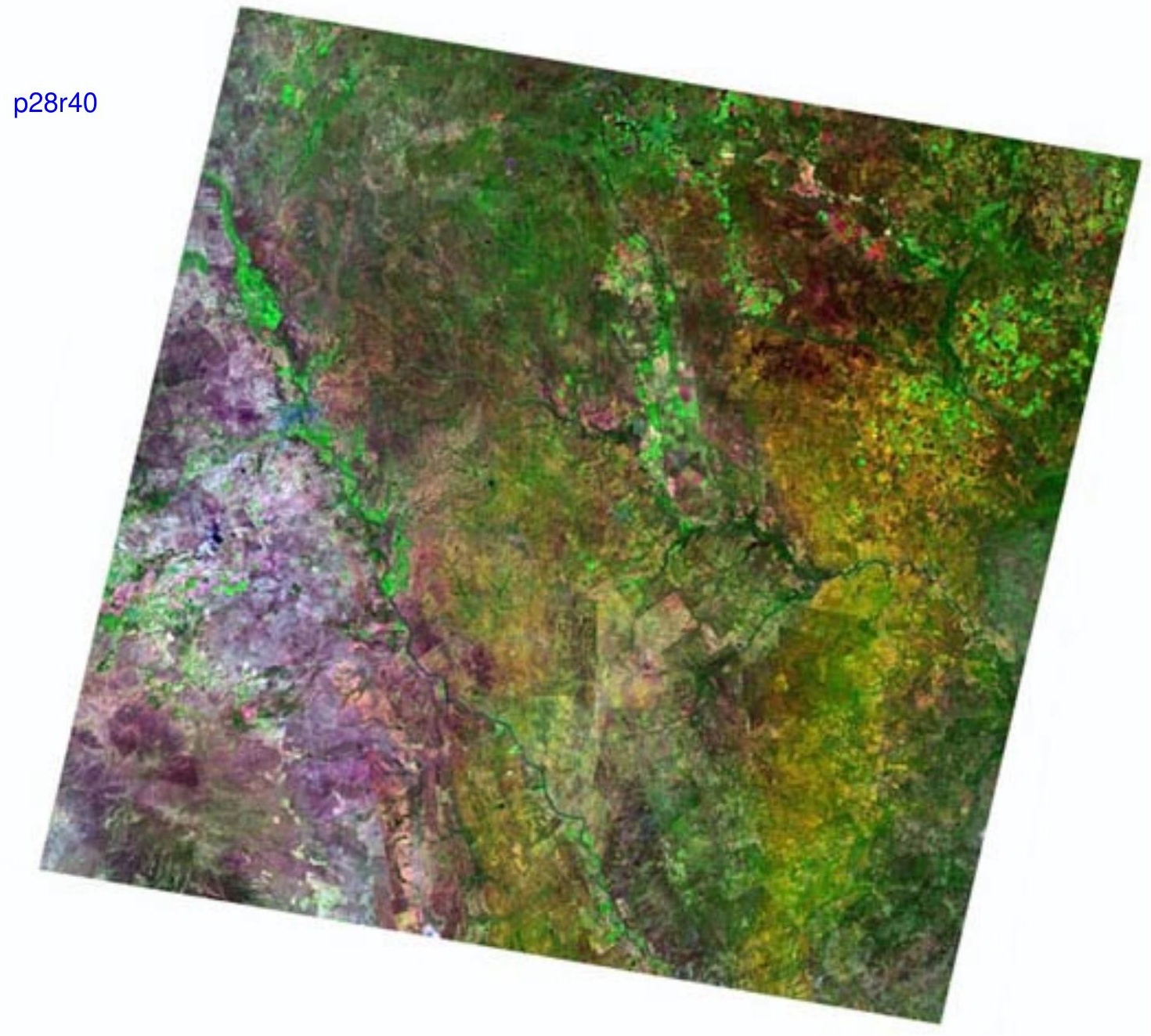


p28r41 
p30r39 


\section{p30r40}

Plines 


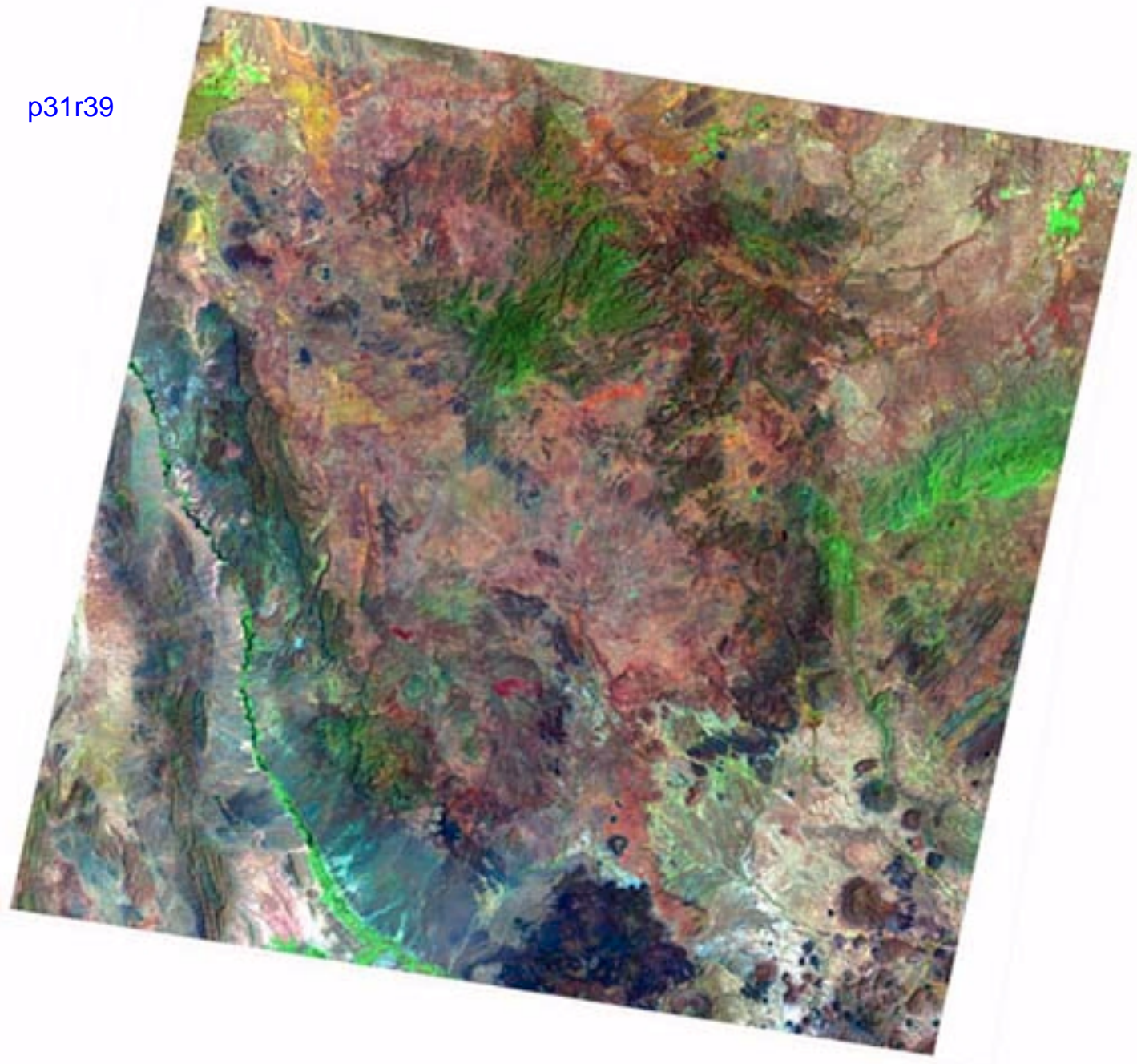




\section{p31r40}




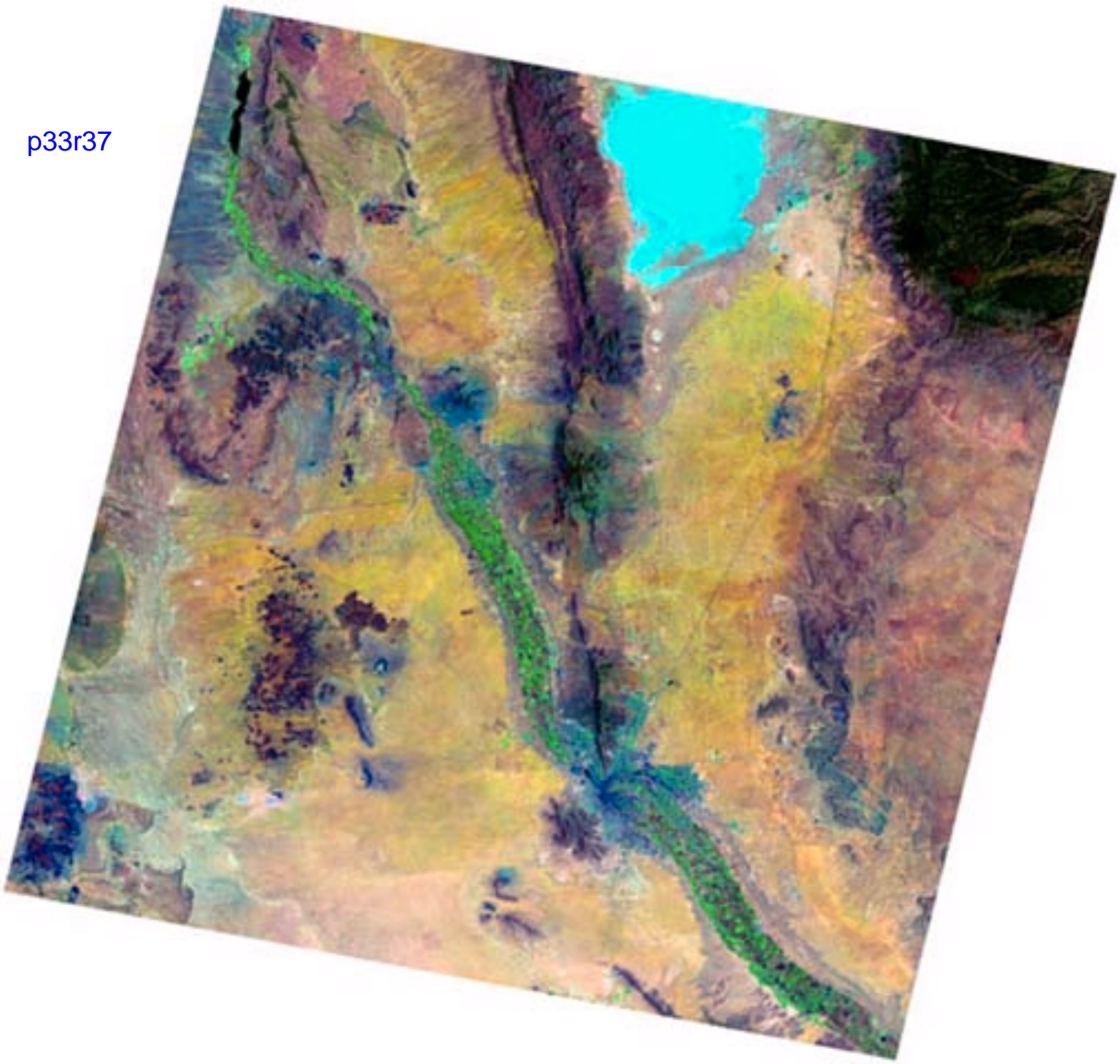




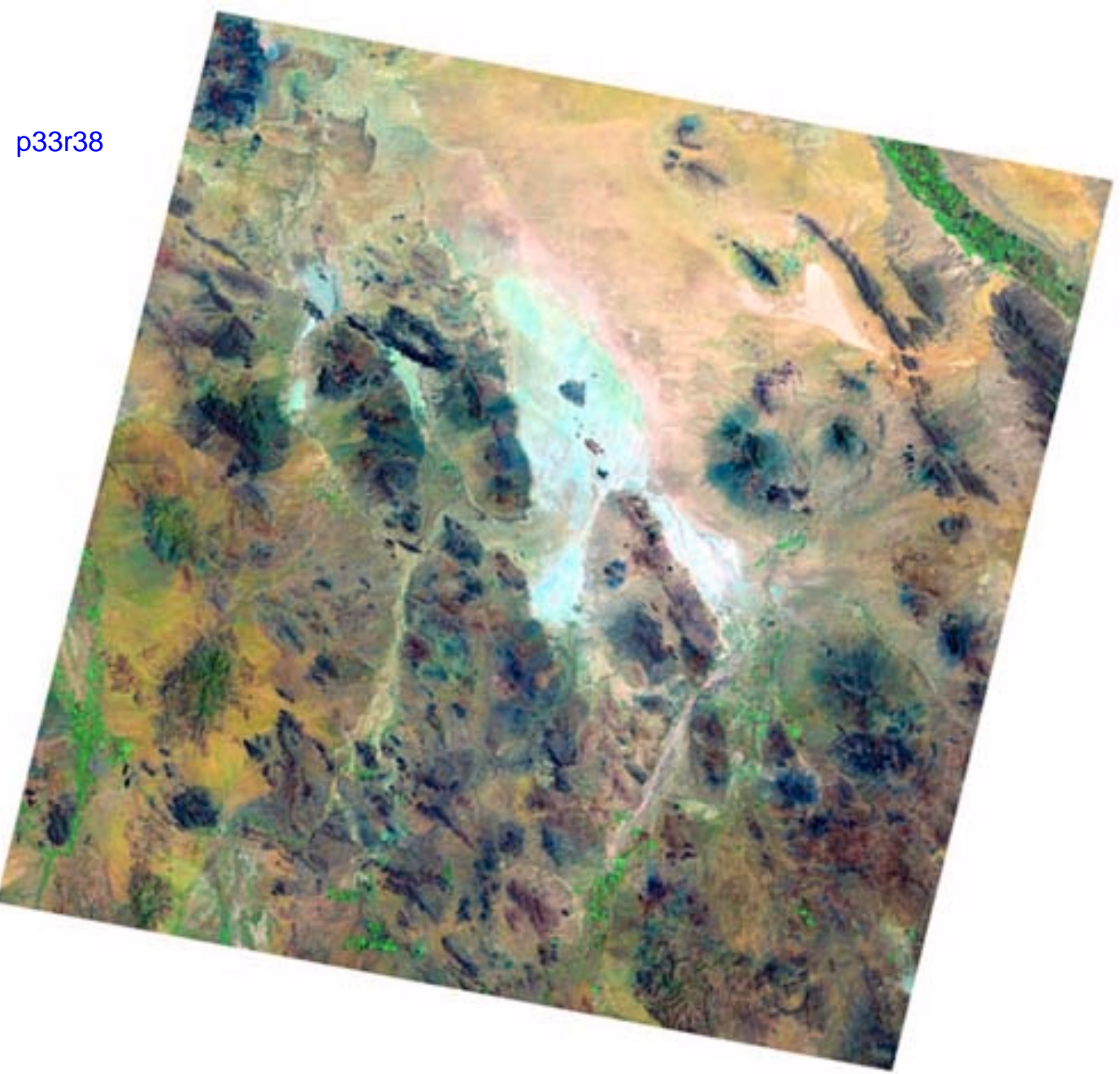




\section{p34r38}

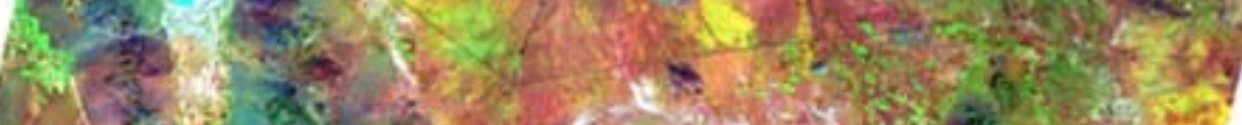

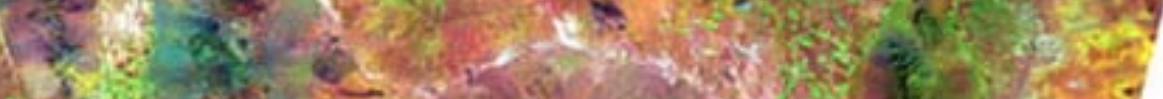
(6)

Sige 
p34r39

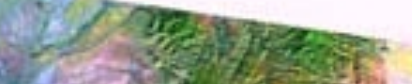

\section{p34r39}

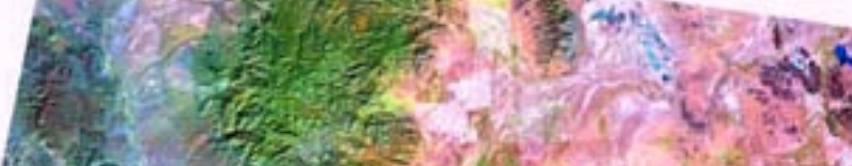

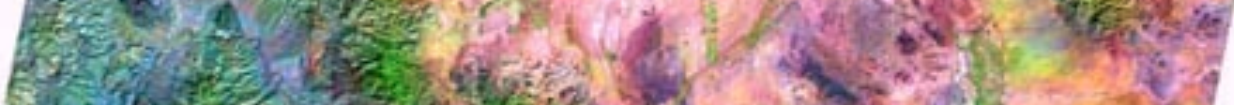

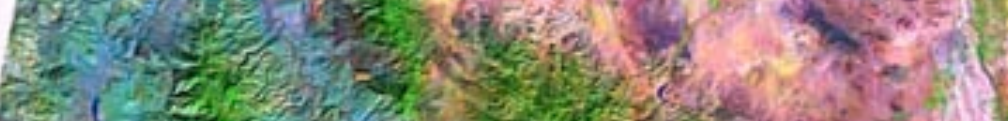
(1)

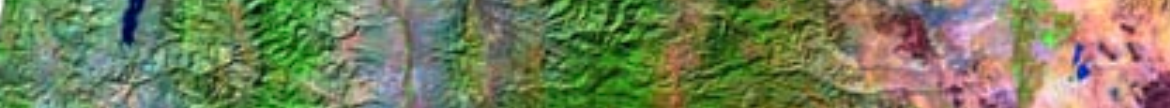

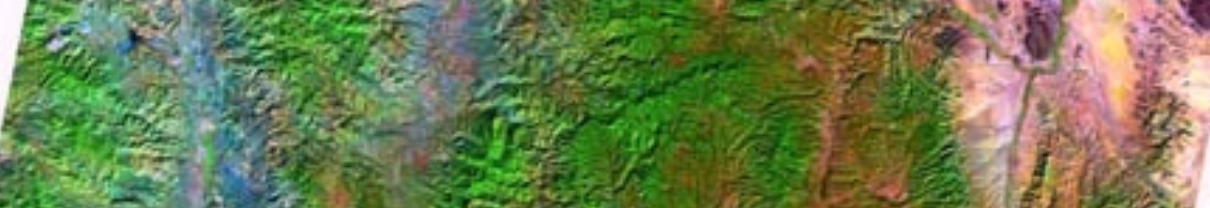

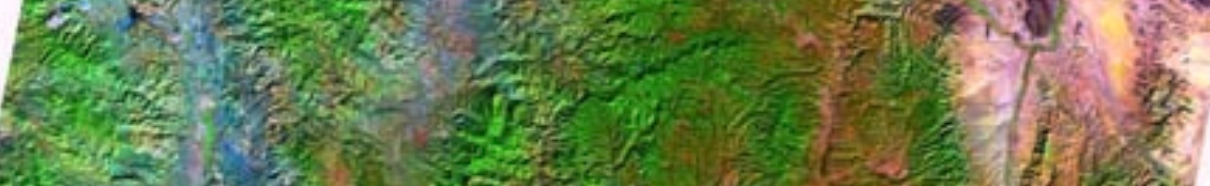

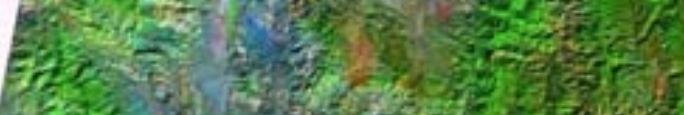

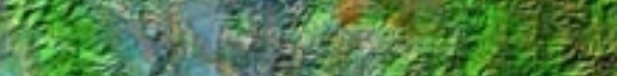

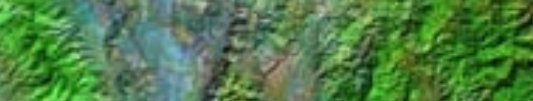

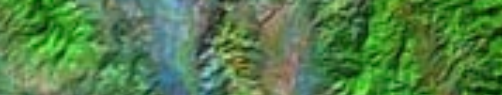
2. rog.

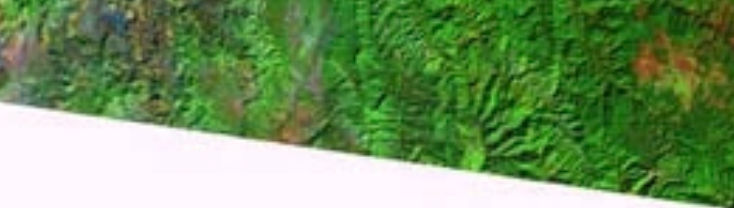




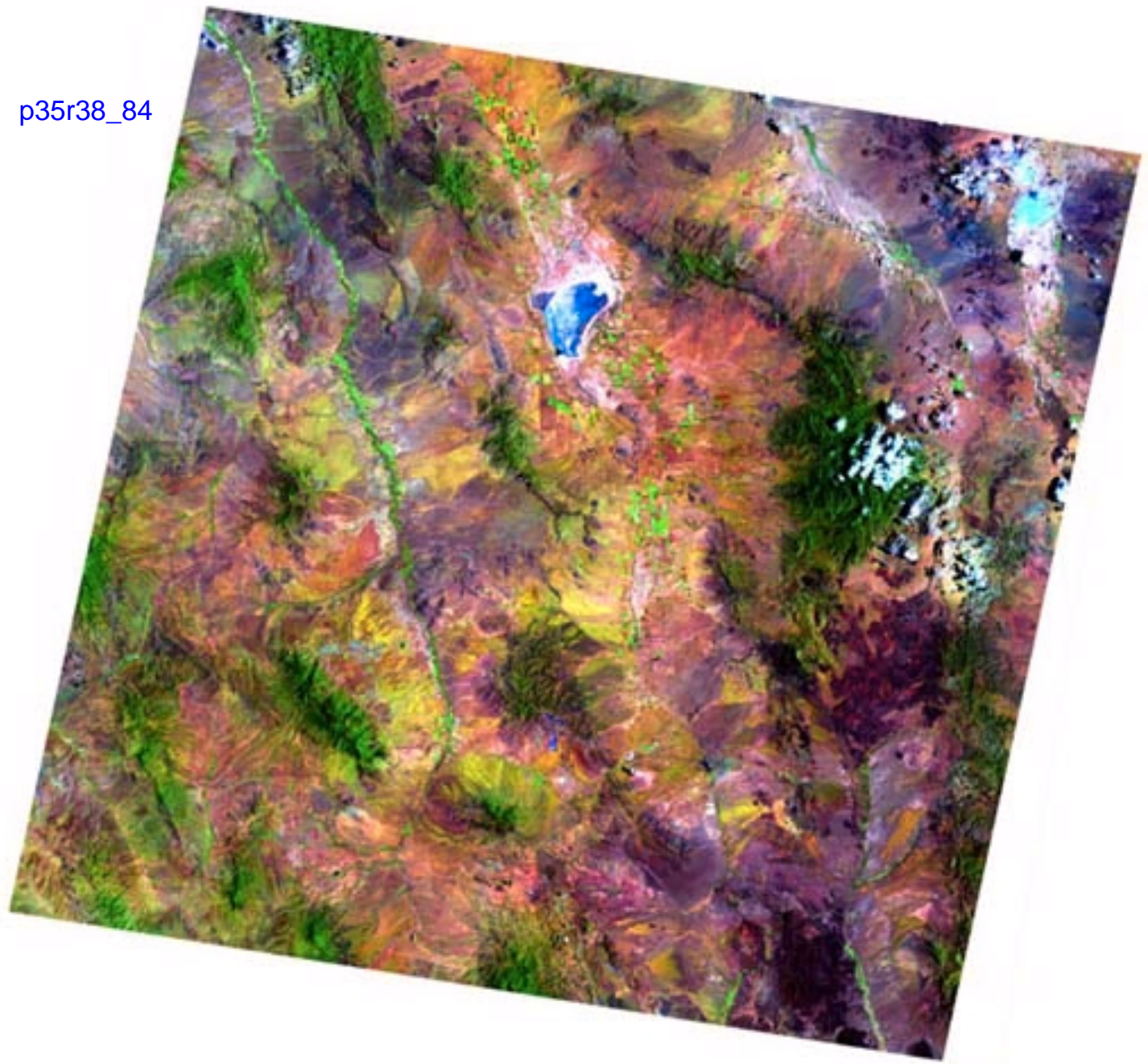




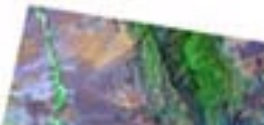

\section{p35r38_97}




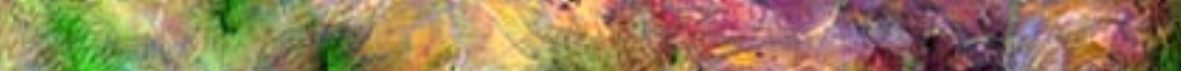

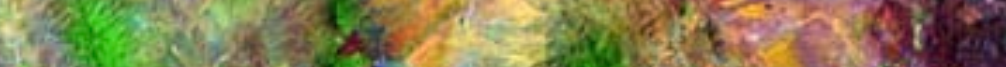

p35r39

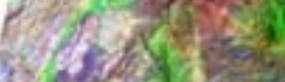

S.

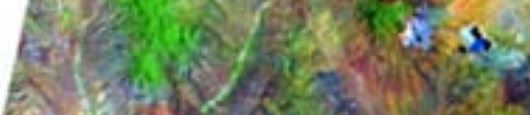

198

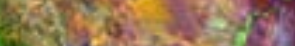

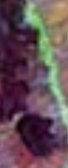

$\sin 20$

19.

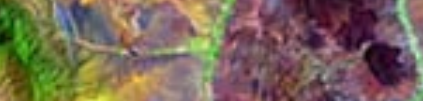

(2)

ris

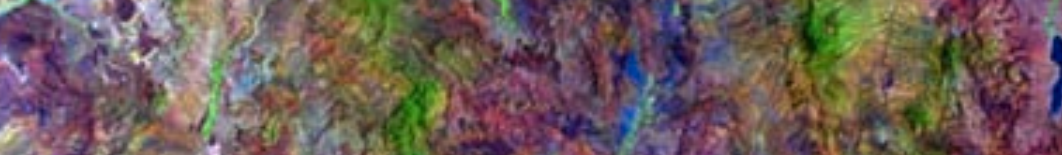

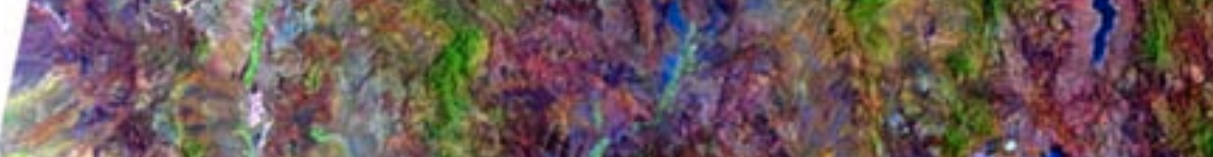

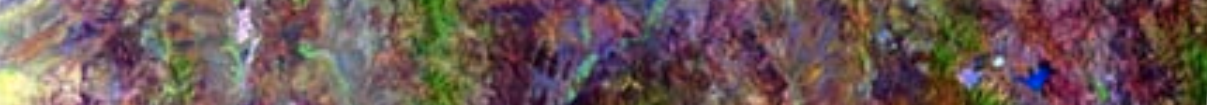
3is. (k)

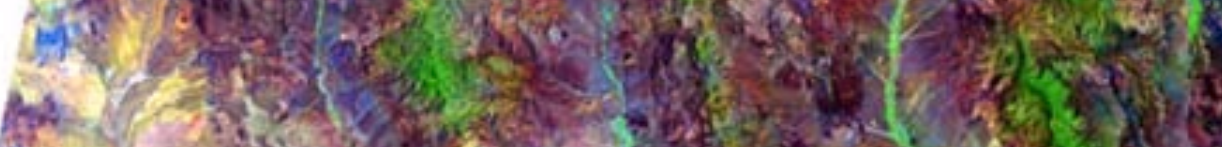
45
34 1
3

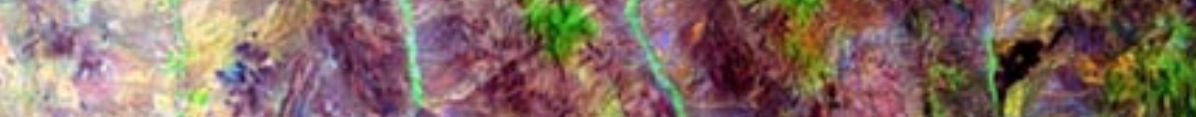
(7)

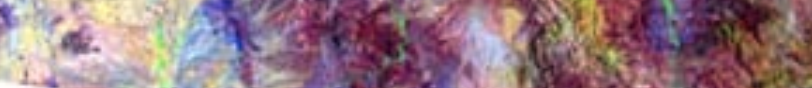



if

p36r39

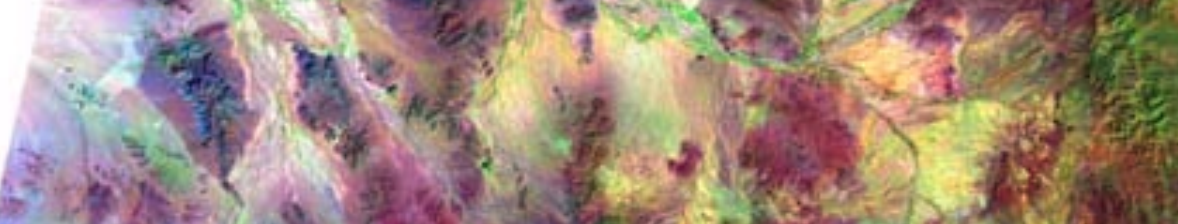

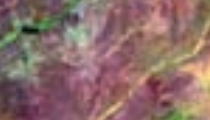




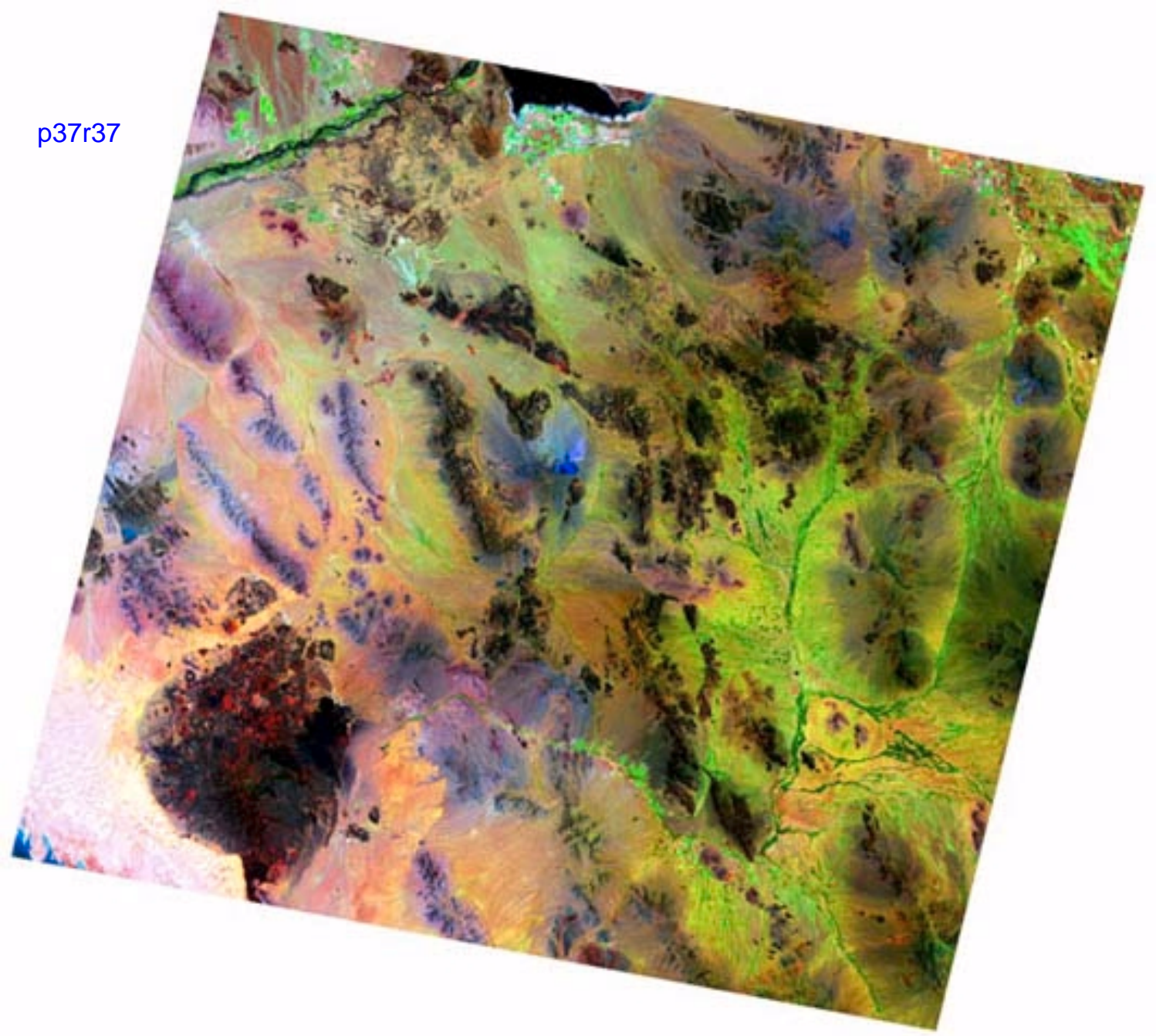




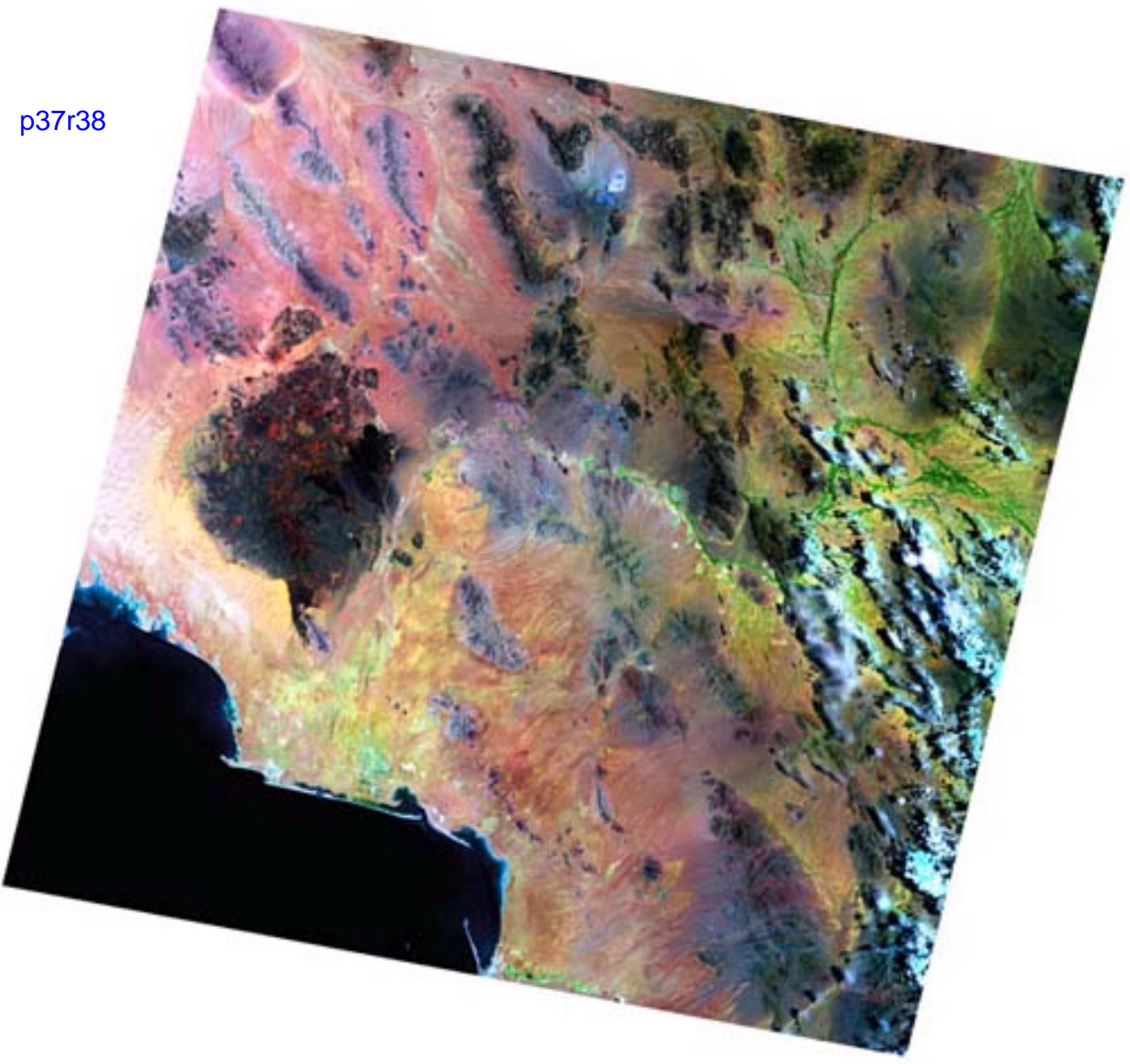




\section{Pron}

\section{p38r37}




\section{p38r38}




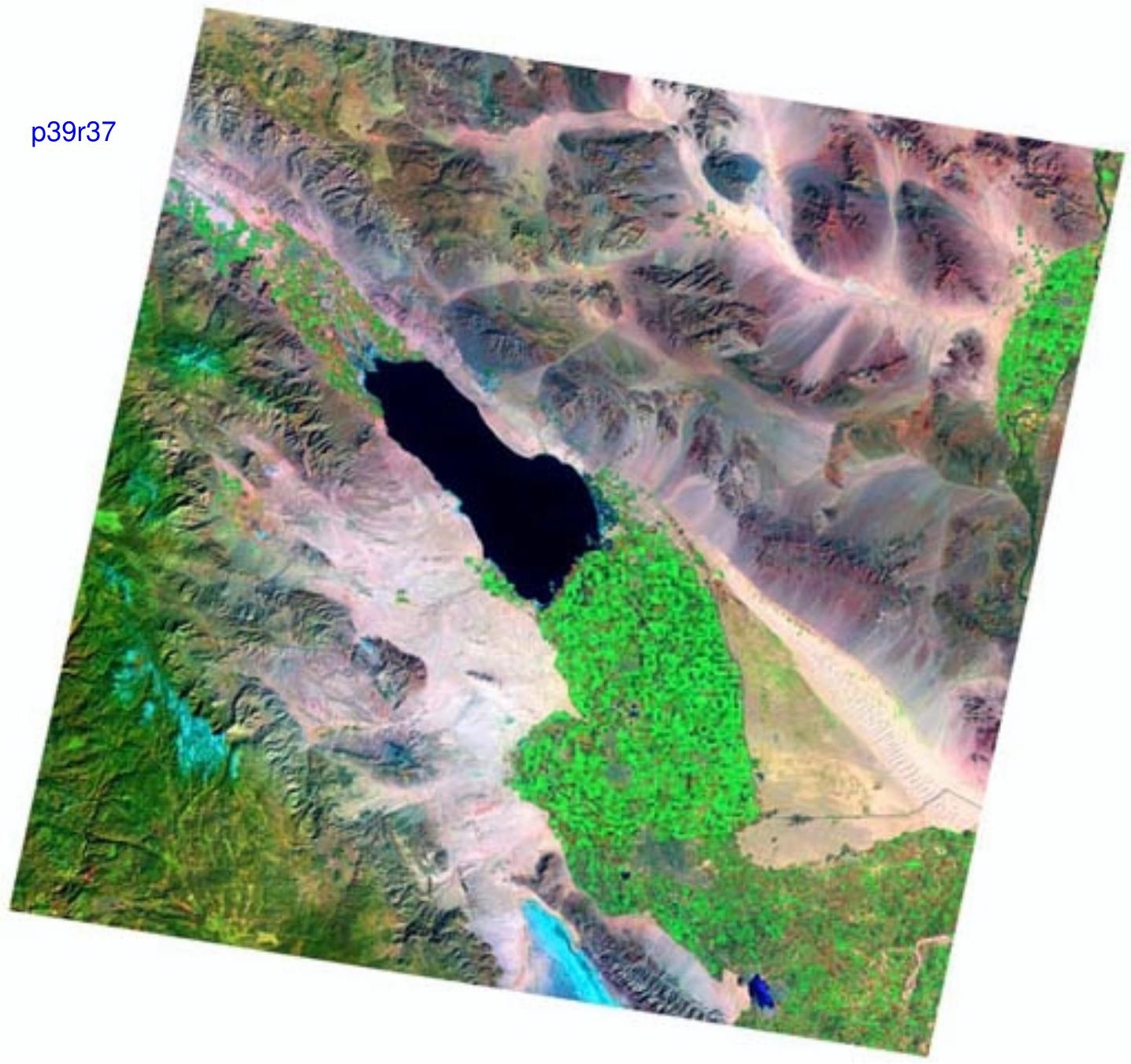




\section{p39r38}




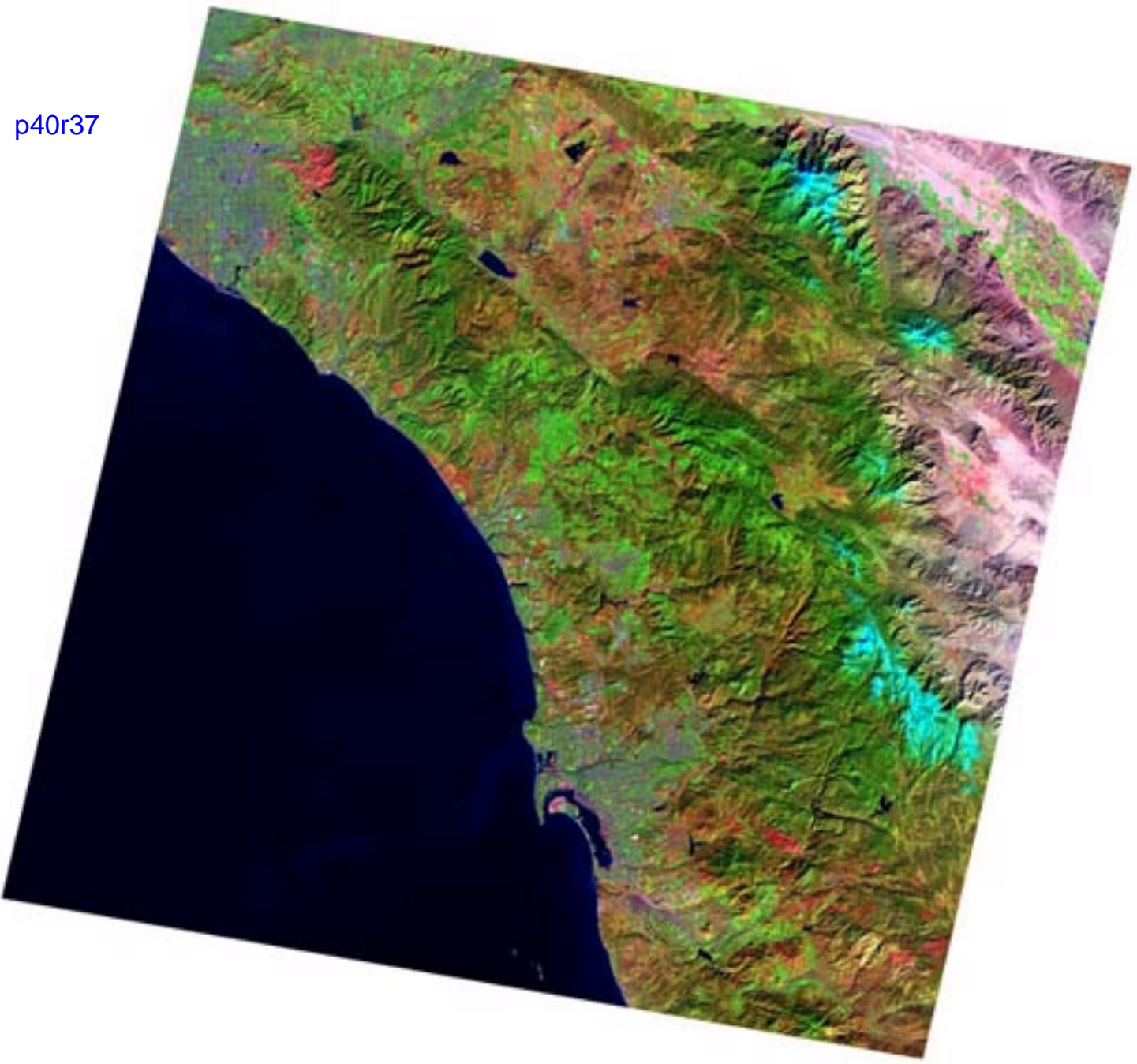

